\title{
Developing Nutrition Awareness in First Year Medical Students
}

\author{
Bruckner Geza*1, Elder William $^{2}$ and Sehnert Scott ${ }^{3}$ \\ ${ }^{1 *}$ Professor Clinical Nutrition, University of Kentucky, Lexington KY \\ ${ }^{2}$ Professor of Family and Community Medicine, University of Kentucky, Lexington KY \\ ${ }^{3}$ Sports Dietician, Auburn University, Alabama
}

${ }^{*}$ Correspondence to: Bruckner Geza, Professor Clinical Nutrition, University of Kentucky, Lexington KY40536, Tel: 859-21808; E-mail: gbruckn@uky.edu

Received: August 10, 2016; Accepted: August 24, 2016; Published: September 24, 2016;

\begin{abstract}
Across the medical training continuum, nutrition education efforts often fail to deliver practical knowledge and current practice, with professional and accrediting organizations recommending expansion of nutrition education within undergraduate and graduate curricula. Conclusions from a review of recent nutrition education efforts strongly recommend that programs "be creative and think out of the box when developing a nutrition curriculum".

\section{Why the Idea or Change was Necessary}

Understanding barriers to change is fundamental to patient counseling. While physicians routinely "prescribe" dietary interventions; no studies describe medical students' nutrition awareness or knowledge of adherence barriers to dietary change. Therefore, this report describes an innovative nutrition experience, "thinking out of the box", to enhance: (1) medical students' food awareness and (2) recognition of barriers to dietary change.

\section{What was Done}

As one topic in a required first-year course, 98 medical students received instruction for completing their own 3-day dietary intake food records. One week later, students were randomly assigned to either a low carbohydrate(Atkins) or low fat(Ornish) diet for three days and 3 day dietary intakes again recorded. The following week students met in nine-member, two hour groups led by nutritionists and family practice physicians. Discussion questions examined: changes in awareness of food intake and eating habits as a result of the diet records; ability to analyze intake in comparison to the Food Guide Pyramid recommendations (study was done prior to the MyPyramid guidelines); sense of controversy surrounding current dietary recommendations; experiences in modifying diet; responses to diet modification; and, changes in personal perspectives or understanding of patients.
\end{abstract}

\section{Evaluation of the Results}

Sixty three percent of the students completed the three-day diet records and 25 each tried the low carbohydrate and high carbohydrate diet, respectively. In group discussions, students indicated that they became more aware of personal diet and eating habits through record keeping. Most found that their diets needed improvement (e.g., inadequate fruits and vegetables). Many did not understand the controversy over recent dietary recommendations. This provided a teachable moment for nutritional principles such as changes in calcium intake, good fats-bad fats, and consumption of whole grains in relation to glycemic index. Students recognized a primary barrier of complexity, expressing concern that "if they had trouble with understanding these changing recommendations then the general public must be very confused." Other barriers recognized were: "being overwhelmed with school; lacking time to follow the diet or prepare foods; limited food choices at school; emotional and energy level changes related to the diet; and, disliking food choices." Students discussed the challenge of change in conflict with circumstances, in their case during examinations, highlighting the importance of timing and social stressors. Students found the exercises to be a worthwhile, helping prepare them for patient-centered care.

Although these assessments are largely subjective, they were gathered systematically, represent this particular student population, and were similar across groups. It appears that students may develop a greater sense of empathy and patient understanding when they experience firsthand their own nutritional inadequacies and challenges.

Key words: Nutrition Education, Dietary Interventions, Atkins Diet, Ornish Diet, Anthropometries

\section{Introduction}

Over 20 years have passed since the National Academy of Sciences recognized that nutrition education was deficient in medical training [1] Medical organizations [1,2] recommended expansion of nutrition education within the undergraduate and graduate curricula and new programs such as the 1997 Nutrition Academic Award (NAA) Program were established to "support the development and enhancement of nutrition curricula for medical students, residents and practicing physicians to learn principles and practice skills in nutrition." From this work a number of new learning methodologies emerged to integrate nutrition into the medical school curricula [4-6]. An important finding, lesson learned from these efforts was "be creative and think out of the box when developing a nutrition curriculum" [7]. 
Because health parameters have been shown to decline in medical students across training,[8] methods and data on student nutrition should be of value to the research community. Regarding food intake and dietary composition of medical students, a brief review of the medical literature revealed only three studies [9-11] describing food intake in medical students outside the United States of America (US A); there were no studies reported for USA medical students. These studies from outside of the USA reported that the nutrition of firstand third- year students was irregular and different in the time and number of meals. Only $20 \%$ of students daily ate $400 \mathrm{~g}$ of fruit and vegetables as recommended by the World Health Organization. Students, especially males, used excessive amounts of animal fat. Every seventh student consumed excess salt and students consumed insufficient amounts of grains and other products that constitute the basis of the pyramid for healthy nutrition. Twenty-three percent of males and nearly as many females used alcohol once per week. Nearly one-half of students did not exercise at all, and $9.1 \%$ of third-year female and $14.5 \%$ of third- year male students were overweight.

The current study examines in one US medical school the food intake and dietary composition of first year medical students obtained during experiential dietary activities.

\section{Methods}

As part of a required first-year course, 98 medical students (55 male; 45 female) were given verbal and written instruction on how to complete detailed, 3-day dietary intake records - including portion sizes, hunger levels, meal settings, and time of meals. Students were also asked to record their weight and height. Also standard dietary intake forms were provided to the students with instructions for filling out the forms.

One week after recording their normal 3-day food intakes, students were randomly assigned to either a low carbohydrate [12] (Atkins) or low fat[13] (Ornish) diet for 3 days; these diets were chosen to represent two contrasting dietary approaches from what was anticipated to be "more normal" for the students. Students assigned to the low carb condition were given 3 keto-sticks and asked to record their urinary ketones. Complete instructions for the Atkins [14] and Ornish[18] diets - as well as meal recipes for these diets- were provided along with websites for these contrasting dietary approaches. Students were instructed to keep 3-day food intake records while on the low carb or low fat diets.

Following these dietary exercises, the medical students met for 2 hours in small, 9-member student groups led by an $\mathrm{RD}$ or $\mathrm{PhD}$ trained nutritionist and a family practice physician. Prior to the group meetings the following five questions were developed to facilitate group discussion and to examine student experiences with the dietary exercises. Faculty preceptors guided the discussion around the following questions: (1) Was your awareness of your dietary intake and eating habits heightened as a result of your personal 3-day diet records? (2) Were you able to analyze your dietary intake in comparison to the Food Guide Pyramid recommendations (study was done prior to the MyPyramid guidelines)? (3) Do you understand the controversy surrounding current dietary recommendations? (4) What experiences did you have modifying your diet and how did you respond to the diet modification? 5) Did your awareness of diet modification help you relate to "patient centered care"? At the end of the discussion period, students were asked to turn in their food records [9-11].

The results reported here summarize these discussions and provide a dietary analysis of food intake. Only complete 3-day diet records for both normal and experiential dietary consumption were analyzed using Nutritionist Pro (Version 2.1, First DataBank, Inc. San Bruno CA) [13]. Kruskal-Wallis and t-tests for independent samples were used as non-parametric (Kruskal-Wallis) and parametric (t-test alternatives, respectively, for determining significant differences between normal diets for males and females and comparison of normal and intervention dietary treatment groups for each gender. $\mathrm{P}$ values were set at $\leq 0.05$ for all analyses. The study was approved by the Institutional Review Board.

\section{Results}

\section{Diet Records}

Sixty two of the 98 students ( 30 females; 32 males) completed the normal 3-day diet records (overall compliance $=63 \%$ ). Of the students assigned to the low carbohydrate diet (Atkins), 8 females (38.1\%) and 17 males (62.9\%) completed the diet records. For students assigned to the Ornish diet, 19 females (90.5\%) and 6 males (22\%) completed the food records.

\section{Anthropometries / Dietary Intake Analysis}

As depicted in Table 1, the average body mass index (BMI) of both male and female students indicated a normal, low-risk BMI (normal range is 18.5 to 24.9$)$.

Table 1. Anthropometric measurements of first-year medical students (Average $\pm \mathrm{SD}$ )

\begin{tabular}{|l|l|l|l|}
\hline & Height (inches) & Weight (lbs) & BMI \\
\hline Male & $70.9 \pm 3.0$ & $179 \pm 29.1$ & $24.9 \pm 3.0$ \\
\hline Female & $64.7 \pm 3.2$ & $127 \pm 16.7$ & $21.4 \pm 2.0$ \\
\hline
\end{tabular}

The average nutrient intake for the medical students consuming their normal diets is shown in Table 2. Not surprisingly, statistically significant $\left(^{*}\right)$ differences exist between males' and females' absolute nutrient intake.

However, with the exception of dietary fiber - which was consumed in higher amounts by females - these differences disappeared when adjusted for bodyweight. More importantly, the data show that many of the nutrients consumed do not meet the dietary recommended intakes (DRIs). That is, females consumed less than $80 \%$ of calcium, iron, vitamin D, E, folate, biotin, pantothenic acid, vitamin K, iodine, magnesium, zinc, copper, selenium, fluoride, molybdenum and fiber (nutrients in italics) than recommended. Males consumed less than $80 \%$ of the DRIs for calcium, vitamin D, E, folate, biotin, pantothenic acid, vitamin $\mathrm{K}$, iodine, magnesium, copper, manganese, chromium, fluoride, molybdenum and fiber [16]. 
Table 2. Average nutrient intake of first-year medical students'3-day "Normal" diet

\begin{tabular}{|c|c|c|c|c|c|c|c|c|c|}
\hline & Units & $\begin{array}{l}\text { Male Student } \\
\text { Average }\end{array}$ & DRI Male & $\begin{array}{c}\text { Female Student } \\
\text { Average }\end{array}$ & $\begin{array}{c}\text { DRI } \\
\text { Female }\end{array}$ & $\begin{array}{c}\text { Male Student } \\
\text { (Average units/Kg) }\end{array}$ & $\begin{array}{l}\text { DRI Male } \\
\text { (U/Kg) }\end{array}$ & $\begin{array}{c}\text { Female Student } \\
\text { (Average units/Kg) }\end{array}$ & $\begin{array}{c}\text { DRI } \\
\text { Female (U/Kg) }\end{array}$ \\
\hline Kilocalories & kcal & $* 2172.0$ & & 1576 & & 27 & & 28 & \\
\hline Protein & $\mathrm{g}$ & $* 93.0$ & 56 & 66 & 46 & 1.1 & 0.7 & 1.1 & 1 \\
\hline Carbohydrate & $\mathrm{g}$ & $* 275.0$ & 130 & 210 & 130 & 3.5 & 1.6 & 3.8 & 2.7 \\
\hline Fat, Total & $\mathrm{g}$ & $* 72.0$ & & 54 & & 0.9 & - & 0.9 & - \\
\hline Alcohol & $\mathrm{g}$ & $* 10.0$ & & 0.7 & & 0.1 & - & 0 & - \\
\hline Cholesterol & $\mathrm{mg}$ & $* 245.0$ & & 172 & & 3 & - & 2.8 & - \\
\hline Saturated Fat & g & $* 24.0$ & & 17.5 & & 0.3 & - & 0.3 & - \\
\hline MUFA & $\mathrm{g}$ & 19 & & 14 & & 0.2 & - & 0.2 & - \\
\hline PUFA & g & 9 & & 7 & & 0.1 & - & 0.1 & - \\
\hline Vitamin A (RE) & $\mathrm{RE}$ & 928 & 900 & 819 & 700 & 11.4 & 11 & 14.4 & 14.6 \\
\hline Vitamin C & $\mathrm{mg}$ & 83 & 90 & 71.7 & 75 & 1.1 & 1.1 & 1.3 & 1.6 \\
\hline Calcium & $\mathrm{mg}$ & *853.0 & $1,000.00$ & 573 & $1,000.00$ & 10.4 & 12.2 & 10 & 20.8 \\
\hline Iron & $\mathrm{mg}$ & 15 & 8 & 13 & 18 & 0.2 & 0.1 & 0.2 & 0.4 \\
\hline Vitamin D & $\mu \mathrm{g}$ & 3 & 5 & 1.8 & 5 & 0 & 0.1 & 0 & 0.1 \\
\hline Vitamin $E$ & $\mathrm{mg}$ & 5 & 15 & 5.1 & 15 & 0.1 & 0.2 & 0.1 & 0.3 \\
\hline Thiamin & $\mathrm{mg}$ & $* 1.4$ & 1.2 & 1.1 & 1.1 & 0 & 0 & 0 & 0 \\
\hline Riboflavin & $\mathrm{mg}$ & $* 1.8$ & 1.3 & 1.3 & 1.1 & 0 & 0 & 0 & 0 \\
\hline Niacin & $\mathrm{mg}$ & $* 21.5$ & 16 & 16.1 & 14 & 0.3 & 0.2 & 0.3 & 0.3 \\
\hline $\begin{array}{l}\text { Pyridoxine } \\
\text { (B6) }\end{array}$ & $\mathrm{mg}$ & $* 1.6$ & 1.3 & 1 & 1.3 & 0 & 0 & 0 & 0 \\
\hline $\begin{array}{l}\text { Folate } \\
\text { (Total) }\end{array}$ & $\mathrm{mg}$ & $* 280.0$ & 400 & 212 & 400 & 3.5 & 4.9 & 3.6 & 8.3 \\
\hline $\begin{array}{l}\text { Cobalamin } \\
\text { (B12) }\end{array}$ & $\mu \mathrm{g}$ & 4.1 & 2.4 & 2.9 & 2.4 & 0.1 & 0 & 0.1 & 0.1 \\
\hline Biotin & $\mu \mathrm{g}$ & 23.5 & 30 & 16 & 30 & 0.3 & 0.4 & 0.3 & 0.6 \\
\hline $\begin{array}{l}\text { Pantothenic } \\
\text { Acid }\end{array}$ & $\mu \mathrm{g}$ & 3.5 & 5 & 2.6 & 5 & 0 & 0.1 & 0.1 & 0.1 \\
\hline Vitamin $K$ & $\mu \mathrm{g}$ & $* 11.7$ & 120 & 39.6 & 90 & 0.1 & 1.5 & 0.7 & 1.9 \\
\hline Phosphorus & $\mathrm{mg}$ & $* 1068.0$ & 700 & 799.7 & 700 & 13.1 & 8.5 & 13.8 & 14.6 \\
\hline Iodine & $\mu \mathrm{g}$ & 15.5 & 150 & 24.7 & 150 & 0 & 1.8 & 0.1 & 3.1 \\
\hline Magnesium & $\mathrm{mg}$ & $* 204.0$ & 400 & 153 & 310 & 2.6 & 4.9 & 2.7 & 6.5 \\
\hline Zinc & $\mathrm{mg}$ & $* 10.0$ & 11 & 6.5 & 8 & 0.1 & 0.1 & 0.1 & 0.2 \\
\hline Copper & $\mathrm{mg}$ & $* 0.8$ & 0.9 & 0.6 & 0.9 & 0 & 0 & 0 & 0 \\
\hline Manganese & $\mathrm{mg}$ & 1.2 & 2.3 & 8.7 & 1.8 & 0 & 0 & 0 & 0 \\
\hline Selenium & $\mu \mathrm{g}$ & $* 65.0$ & 55 & 40.3 & 55 & 0.8 & 0.7 & 0.7 & 1.2 \\
\hline Fluoride & $\mu \mathrm{g}$ & *501.0 & 400 & 230.7 & 300 & 5.9 & 4.9 & 4.4 & 6.3 \\
\hline Chromium & $\mu \mathrm{g}$ & 0 & 0.3 & 0.5 & 0.3 & 0 & 0 & 0 & 0 \\
\hline Molybdenum & $\mu \mathrm{g}$ & 17 & 45 & 15.3 & 45 & 0.2 & 0.6 & 0.3 & 0.9 \\
\hline Dietary Fiber & g & $* 15.0$ & 38 & 13.4 & 25 & $* 0.2$ & 0.5 & 0.2 & 0.5 \\
\hline Sugar, Total & g & $* 104.0$ & & 73.6 & & 1.3 & - & 1.4 & - \\
\hline Caffeine & $\mathrm{mg}$ & 98 & & 77 & & 1.2 & - & 1.3 & - \\
\hline
\end{tabular}

FOOTNOTE: Data are expressed as absolute units/day and as units/Kg body weight ( $82 \mathrm{Kg}$ as average weight for males and $48 \mathrm{Kg}$ as average weight for females) $(*=\mathrm{p} \leq 0.05$ for comparison between Male and Female student) (italics = consumption of less than $80 \%$ of DRI) 
The dietary intakes of students on the Atkins or Ornish diets, compared to their normal dietary intake, are illustrated in Tables 3 and 4. Compared to the male students, it appears that the female students assigned to the Atkins diet showed better adherence - as noted by the trend toward increased protein and fat intake and decreased carbohydrate intake. There were no differences in adherence noted for male students who "normally" consumed a higher protein/high fat diet. Both males and females assigned to the Ornish diet showed similar lower intakes of total calories, protein, and fat [13].

Table 3. Comparison of medical students" "Normal" versus Atkins diets

\begin{tabular}{|c|c|c|c|c|c|}
\hline & Units & $\begin{array}{c}\text { Male } \\
\text { Normal }\end{array}$ & $\begin{array}{c}\text { Male } \\
\text { Atkins }\end{array}$ & $\begin{array}{l}\text { Female } \\
\text { Normal }\end{array}$ & $\begin{array}{l}\text { Female } \\
\text { Atkins }\end{array}$ \\
\hline Kilocalories & kcal & 2482 & 2121 & 1576 & 1180 \\
\hline Protein & $\mathrm{g}$ & 109 & 92 & 66 & 96 \\
\hline Carbohydrate & g & 308 & 250 & 210 & $* 40.0$ \\
\hline Fat, Total & g & 85 & 74 & 54 & 69 \\
\hline Alcohol & $\mathrm{g}$ & 9 & 14 & 0.7 & 0.4 \\
\hline Cholesterol & $\mathrm{mg}$ & 283 & 261 & 172 & 534 \\
\hline Saturated Fat & $\mathrm{g}$ & 30 & 25 & 17.5 & 23 \\
\hline MUFA & g & 21 & 21 & 14 & 23 \\
\hline PUFA & g & 10.2 & 9.2 & 7 & 11 \\
\hline Vitamin A (RE) & $\mathrm{RE}$ & 1100 & 769 & 819 & 594 \\
\hline Vitamin C & $\mathrm{mg}$ & 111 & 53 & 71.7 & 32.3 \\
\hline Calcium & $\mathrm{mg}$ & 1028 & 801 & 573 & 437 \\
\hline Iron & $\mathrm{mg}$ & 20 & $* 14.0$ & 13 & 7.4 \\
\hline Vitamin D & $\mu \mathrm{g}$ & 3.9 & 2.9 & 1.8 & 1.7 \\
\hline Vitamin E & $\mathrm{mg}$ & 7.5 & 4.3 & 5.1 & 4.1 \\
\hline Thiamin & $\mathrm{mg}$ & 1.8 & 1.3 & 1.1 & 0.7 \\
\hline Riboflavin & $\mathrm{mg}$ & 2.3 & 1.7 & 1.3 & 1.3 \\
\hline Niacin & $\mathrm{mg}$ & 24.5 & 21.9 & 16.1 & 21.7 \\
\hline Pyridoxine (B 6) & $\mathrm{mg}$ & 1.9 & 1.5 & 1 & 1.3 \\
\hline Folate (Total) & $\mathrm{mg}$ & 327 & 262 & 212 & 173 \\
\hline Cobalamin (B12) & $\mu \mathrm{g}$ & 4.1 & 6.2 & 2.9 & 5.1 \\
\hline Biotin & $\mu \mathrm{g}$ & 42.4 & 15.5 & 16 & 18.7 \\
\hline Pantothenic Acid & $\mu \mathrm{g}$ & 5 & 3 & 2.6 & 3.9 \\
\hline Vitamin K & $\mu \mathrm{g}$ & 15 & 9.7 & 39.6 & 75.5 \\
\hline Phosphorus & $\mathrm{mg}$ & 1283 & 1003 & 799 & 980 \\
\hline Iodine & $\mu \mathrm{g}$ & 20 & 0 & 24.7 & 12.5 \\
\hline Magnesium & $\mathrm{mg}$ & 249 & 183 & 153 & 123 \\
\hline Zinc & $\mathrm{mg}$ & 13.6 & 9 & 6.5 & 8.1 \\
\hline Copper & $\mathrm{mg}$ & 1 & 0.8 & 0.6 & 0.5 \\
\hline Manganese & $\mathrm{mg}$ & 1.6 & 0.9 & 8.7 & 0.6 \\
\hline Selenium & $\mu \mathrm{g}$ & 77.6 & 61.6 & 40.3 & 90 \\
\hline Fluoride & $\mu \mathrm{g}$ & 610 & 499 & 230.7 & 220 \\
\hline Chromium & $\mu \mathrm{g}$ & 0 & 0 & 0.5 & 0 \\
\hline Molybdenum & $\mu \mathrm{g}$ & 21.5 & 15.3 & 15.3 & 20.5 \\
\hline Dietary Fiber & $\mathrm{g}$ & 18.4 & 13.8 & 13.4 & 4.1 \\
\hline Sugar, Total & g & 115.1 & 80.6 & 73.6 & 16.2 \\
\hline Caffeine & $\mathrm{mg}$ & 127.5 & 87 & 77 & 75 \\
\hline
\end{tabular}

$*=p \leq 0.05$ for comparison between Normal and Atkins diet
Table 4. Comparison of medical students" "Normal" versus Ornish diets

\begin{tabular}{|c|c|c|c|c|c|}
\hline & Units & $\begin{array}{c}\text { Male } \\
\text { Normal }\end{array}$ & $\begin{array}{l}\text { Male } \\
\text { Ornish }\end{array}$ & $\begin{array}{l}\text { Female } \\
\text { Normal }\end{array}$ & $\begin{array}{l}\text { Female } \\
\text { Ornish }\end{array}$ \\
\hline Kilocalories & kcal & $2,172.00$ & 1692.6 & 1576 & 1252.3 \\
\hline Protein & g & 93 & 65.2 & 66 & 46.4 \\
\hline Carbohydrate & g & 275 & 266.2 & 210 & 201.8 \\
\hline Fat, Total & g & 72 & 45.3 & 54 & 30.8 \\
\hline Alcohol & $\mathrm{g}$ & 10 & 0.6 & 0.7 & 2.7 \\
\hline Cholesterol & $\mathrm{mg}$ & 245 & 168 & 172 & 72.3 \\
\hline Saturated Fat & g & 24 & 14.8 & 17.5 & 8.7 \\
\hline MUFA & g & 19 & 10.5 & 14 & 7.8 \\
\hline PUFA & $\mathrm{g}$ & 9 & 5.8 & 7 & 5.4 \\
\hline Vitamin A (RE) & $\mathrm{RE}$ & 928 & 1385.8 & 819 & 1031.4 \\
\hline Vitamin C & $\mathrm{mg}$ & 83 & 203.6 & 71.7 & 120.1 \\
\hline Calcium & $\mathrm{mg}$ & 853 & 675.1 & 573 & 586.4 \\
\hline Iron & $\mathrm{mg}$ & 15 & 13.2 & 13 & 12.3 \\
\hline Vitamin D & $\mu \mathrm{g}$ & 3 & 2.4 & 1.8 & 2.3 \\
\hline Vitamin E & $\mathrm{mg}$ & 5 & 7.6 & 5.1 & 5.2 \\
\hline Thiamin & $\mathrm{mg}$ & 1.4 & 2.5 & 1.1 & 1.6 \\
\hline Riboflavin & $\mathrm{mg}$ & 1.8 & 1.3 & 1.3 & 1.1 \\
\hline Niacin & $\mathrm{mg}$ & 21.5 & 16.5 & 16.1 & 12.9 \\
\hline Pyridoxine (B6) & $\mathrm{mg}$ & 1.6 & 1.4 & 1 & 1.2 \\
\hline Folate (Total) & $\mathrm{mg}$ & 280 & 306.8 & 212 & 318.7 \\
\hline Cobalamin (B12) & $\mu \mathrm{g}$ & 4.1 & 3.2 & 2.9 & 2.6 \\
\hline Biotin & $\mu \mathrm{g}$ & 23.5 & 28.5 & 16 & 20.6 \\
\hline Pantothenic Acid & $\mu \mathrm{g}$ & 3.6 & 3.3 & 2.6 & 2.7 \\
\hline Vitamin $\mathrm{K}$ & $\mu \mathrm{g}$ & 11.7 & 47.1 & 39.6 & 43.7 \\
\hline Phosphorus & $\mathrm{mg}$ & 1068 & 817.2 & 799.7 & 691.1 \\
\hline Iodine & $\mu \mathrm{g}$ & 15.5 & 22.4 & 24.7 & 17.5 \\
\hline Magnesium & $\mathrm{mg}$ & 204 & 218.4 & 153 & 203.6 \\
\hline Zinc & $\mathrm{mg}$ & 10 & 7.9 & 6.5 & 6.1 \\
\hline Copper & $\mathrm{mg}$ & 0.8 & 1 & 0.6 & 0.7 \\
\hline Manganese & $\mathrm{mg}$ & 1.2 & 1.3 & 8.7 & 1.7 \\
\hline Selenium & $\mu \mathrm{g}$ & 65 & 41.1 & 40.3 & 39.3 \\
\hline Fluoride & $\mu \mathrm{g}$ & 501 & 289.2 & 230.7 & 529.1 \\
\hline Chromium & $\mu \mathrm{g}$ & 0 & 0.1 & 0.5 & 0.03 \\
\hline Molybdenum & $\mu \mathrm{g}$ & 17 & 16.2 & 15.3 & 13.5 \\
\hline Dietary Fiber & $\mathrm{g}$ & 15 & 18.3 & 13.4 & 18.9 \\
\hline Sugar, Total & $\mathrm{g}$ & 104 & 109 & 73.6 & 64.7 \\
\hline Caffeine & $\mathrm{mg}$ & 98 & 55 & 77 & 49.6 \\
\hline
\end{tabular}

$*=p \leq 0.05$ for comparison between Normal and Ornish diet

\section{Small Group Discussions}

\section{Impact of exercise on awareness of personal dietary practices}

When asked in the small group discussions whether or not they became more aware of their dietary intake and eating habits by keeping a diet record, the majority of students agreed - regardless of whether they partially or fully completed the 3-day food record. Not unexpectedly, most recognized that their diets needed improvement [16]. 


\section{Ability to analyze personal dietary practices}

As in the general population[1], most students reported less than the recommended intake of fruits and vegetables per the Food Guide Pyramid guidelines. Interestingly, most students did not understand the current controversy over dietary recommendations - which provided prime fodder for further small group discussion. Examples of topics included the recommendations for changes in calcium intake, good fats-bad fats, and increased consumption of nuts, whole grains and glycemic index. Students expressed concern that "if they had trouble with understanding these changing recommendations then the general public must be very confused".

\section{Perceptions of dietary modification}

Students' responses to the question "What experiences did you have through modification of your diet and how did you respond to the diet modification?" were extremely varied. Some typical responses, similar to what might be expressed by patients trying dietary interventions, were

- "I was overwhelmed with school and didn't have time to follow the diet."

- "Food choices were limited at school and I didn't have time to prepare the food!"

- "Tried it - but it was too much trouble."

- "At the end of the day, I was lethargic and cranky because of the diet."

- "Didn't like the food choices."

\section{Impact on understanding of patients that might enhance patient centered care}

Other negative experiences also enabled students to become cognizant of the barriers their patients might face if they were instructed to successfully plan and follow a diet. For example, students faced with a major dietary change during course examinations indicated particular frustration with adherence - highlighting the importance of timing and social stressors. Lastly, all faculty preceptors reported that the majority of students in their small group settings found the dietary exercises to be a worthwhile and that the experience helped them better relate to "patient-centered care" with greater awareness and empathy.

\section{Discussion}

The adequacy of nutrition instruction in undergraduate medical education remains an issue of concern, [17] and progress to integrate nutrition into medical school curricula was the topic of discussion at a the 2005 Experimental Biology Symposium [18] - which yielded the following observations: (1) students currently receive 23.9 contact hours of nutrition instruction during medical school (range: 2-70 hours); (2) only 40 schools require the minimum 25 hours recommended by the National Academy of Sciences; (3) most instructors (88\%) expressed the need for additional nutrition instruction at their institutions; (4) a substantial portion of the total nutrition instruction occurs outside courses specifically dedicated to nutrition; and (5) the amount of nutrition education in medical schools remains inadequate [15]. Unfortunately little has changed in the last ten years as recently reported in an article on "The State of Nutrition Education at US
Medical Schools [19]; "Most US medical schools (86/121,71\%) fail to provide the recommended minimum 25 hours of nutrition education; $43(36 \%)$ provide less than half that much. Nutrition instruction is still largely confined to preclinical courses, with an average of 14.3 hours occurring in this context. Less than half of all schools report teaching any nutrition in clinical practice; practice accounts for an average of only 4.7 hours overall."

To address this inadequacy, the present study demonstrates an innovative means of introducing meaningful nutrition education into the medical school curriculum in an experiential manner that raises self-awareness and awareness of patient concerns $[17,18]$. Although these assessments are largely subjective, it appears that students may develop a greater sense of empathy and understanding related to others when they experience firsthand their own nutritional inadequacies and difficulties altering eating behaviors.

\section{Acknowledgments}

This work was supported by NIH grant 5 R25 AT000682-05.

\section{References}

1. National Academy of Sciences (1985) Nutrition education in U.S. medical schools. Washington, DC: National Academy Press.

2. National Nutritional Monitoring and Related Research Act of 1990. Public Law 1101-445/HR 1608: 302.

3. Pearson TA, Stone EJ, Grundy SM, McBride PE, Van Horn L, et al. (2001) Translation of nutritional sciences into medical education: the Nutrition Academic Award Program. Am J Clin Nutr74: 164-170. [crossref]

4. Tobin B, Welch K, Dent M, Smith C, Hooks B, et al. (2003) Longitudinal and horizontal integration of nutrition science into medical school curricula. J Nutr 133: horizontal integration
$567 \mathrm{~S}-72 \mathrm{~S}$. [crossref]

5. Eaton CB, McBride PE, Gans KA, Underbakke GL (2003) Teaching nutrition skills to primary care practitioners. $J$ Nutr $133: 563 \mathrm{~S}-6 \mathrm{~S}$. [crossref]

6. Carson JA (2003) Pocket tape measure for waist circumference: training medical students and residents on a simple assessment of body composition. J Nutr 133: 547S-9S. [crossref]

7. Hark LA (2006) Lessons learned from nutrition curricular enhancements. Am J Clin Nutr 83: 968S-970S. [crossref]

8. Mitchell SD, Eide R, Olsen CH, Stephens MB (2008) Body composition and physical fitness in a cohort of US military medical students. J Am Board Fam Med 21: $165-167$. [crossref]

9. Tengvall M, Lars Ellegard MS. Dietary intake in Swedish medical students. Scan J Food \& Nutrition, Volume 51, Issue 22007 , pages 79-84

10. Mammas I, Bertsias G, Linardakis M, Moschandreas J, Kafatos A (2004) Nutrient intake and food consumption among medical students in Greece assessed during a Clinical Nutrition course. Int J Food Sci Nutr 55: 17-26. [crossref]

11. Aoki S1, Endo T, Hasegawa H, Nakaji S, Sugawara K, et al. (1996) [Dietary patterns and intake of nutrients, energy, and dietary fiber in medical students]. Nihon Koshu Eisei Zasshi 43: 632-643. [crossref]

12. Foster GD, Wyatt HR, Hill JO, McGuckin BG, Brill C, et al. (2003) A randomized trial of a low-carbohydrate diet for obesity. N Engl J Med 348: 2082-2090. [crossref]

13. Ornish D, Scherwitz LW, Billings JH, Brown SE, Gould KL, et al. (1998) Intensive lifestyle changes for reversal of coronary heart disease. JAMA 280: 2001-2007. [crossref]

14. Atkins Diet - home page http://atkins.com/10/10/2004 updated 7/11/2008

15. Ornish Diet - home page http://my.webmd.com/content/pages/9/3068_9408.htm. 10/10/2004 updated 7/11/2008

16. Guenther PM, Dodd KW, Reedy J, Krebs-Smith SM (2006) Most Americans eat much less than recommended amounts of fruits and vegetables. J Am Diet Assoc 106: 1371-1379. [crossref]

17. Adams KM, Lindell KC, Kohlmeier M, Zeisel SH (2006) Status of nutrition education in medical schools. Am J Clin Nutr 83: 941S-944S. [crossref]

18. (No authors listed) (2005) An evidence-based approach to medical nutrition education. Proceedings of a symposium held at Experimental Biology. Am J Clin Nutr 83: 929S-987S.

19. Adams KM, Butsch WS, Kohlmeier M (2015) The State of Nutrition Education at US Medical Schools. J Biomed Edu Article ID 357627, http://dx.doi. org $/ 10.1155 / 2015 / 357627$

\section{Citation:}

Bruckner Geza, Elder William and Sehnert Scott (2016) Developing Nutrition Awareness in First Year Medical Students. Internal Med Res Open J Volume 1(1): $1-5,2016$ 